\title{
COVID-19 Spread Patterns Is Unrelated to Malaria Co-Infections in Lagos, Nigeria
}

\author{
Olufemi Samuel Amoo' ${ }^{1}$, , Olugbenga Olanrewaju Aina², Azuka Patrick Okwuraiwe1, \\ Chika Kingsley Onwuamah'1, Joseph Ojonugwa Shaibu', Fehintola Ige', Kelly Owaneze', \\ Hammed Olanrewaju Agboola1, Dorcas Njeri Kareithi ${ }^{3}$, Tochukwu Ifeanyi Onuigbo', \\ Amaka Stephanie Ikemefuna1, Joy Isioma Oraegbu1, Ebenezer Olusoji Odewale1, \\ Leona Chika Okoli ${ }^{1}$, Olusola Ajibaye ${ }^{2}$, Ayorinde Babatunde James ${ }^{2}$, Ganiyu Idris' ${ }^{1}$, \\ Greg Ohihoin', Bosun Tijani ${ }^{3}$, Temmie Giwa-Tunbosun ${ }^{4}$, Richard Adegbola1, \\ Babatunde Lawal Salako1, Rosemary Ajuma Audu1
}

\author{
${ }^{1}$ Centre for Human Virology and Genomics, Microbiology Department, Nigerian Institute of Medical Research, Lagos, Nigeria \\ ${ }^{2}$ Biochemistry Department, Nigerian Institute of Medical Research, Lagos, Nigeria \\ ${ }^{3}$ Co-Creation Hub, Lagos, Nigeria \\ ${ }^{4}$ Lifebank, Lagos, Nigeria \\ Email: fhemy2003@yahoo.com
}

How to cite this paper: Amoo, O.S., Aina, O.O., Okwuraiwe, A.P., Onwuamah, C.K., Shaibu, J.O., Ige, F., Owaneze, K., Agboola, H.O., Kareithi, D.N., Onuigbo, T.I., Ikemefuna, A.S., Oraegbu, J.I., Odewale, E.O., Okoli, L.C., Ajibaye, O., James, A.B., Idris, G., Ohihoin, G., Tijani, B., Giwa-Tunbosun, T., Adegbola, R., Salako, B.L. and Audu, R.A. (2020) COVID-19 Spread Patterns Is Unrelated to Malaria Co-Infections in Lagos, Nigeria. Advances in Infectious Diseases, 10, 200-215.

https://doi.org/10.4236/aid.2020.105018

Received: September 3, 2020

Accepted: October 17, 2020

Published: October 20, 2020

Copyright $\odot 2020$ by author(s) and Scientific Research Publishing Inc. This work is licensed under the Creative Commons Attribution International License (CC BY 4.0).

http://creativecommons.org/licenses/by/4.0/ (c)

\begin{abstract}
Malaria and COVID-19, though caused by different organisms, share a significant number of symptoms like fever, headaches, difficulty in breathing and fatigue. Therefore, determining if a patient is positive for COVID-19 or Malaria based on symptoms alone, might be misleading, especially during pandemic response. It has been reported that an individual begins to manifest Malaria symptoms between 10 - 15 days after infection with malaria parasite, although some individuals may be asymptomatic. Some COVID-19 infected patients, like Malaria, are also asymptomatic but could contribute to transmission of SARS-CoV-2 virus. These similarities in symptoms have led to misconception about COVID-19 being real and misdiagnoses of both infections, especially in Nigeria. However, there are possibilities that Malaria and COVID-19 could co-exist in some individuals thereby leading to mismanagement and treatment of only one infection while neglecting the possibility of the patient being infected with both diseases. We aim to determine possible correlation between Malaria and COVID-19 in a Malaria endemic country like Nigeria. This study was carried out using the qPCR molecular testing approach, a gold standard for COVID-19 testing and rapid diagnostic test kits to detect Malaria parasites in 617 individuals residing in urban settings. We demonstrated that COVID-19 and Malaria infection amongst adults in urban settings are unrelated thereby focusing on symptoms alone may result in misdiagnosis. Our findings show that Malaria is not among the underlying med-
\end{abstract}


ical conditions strongly associated with increased risk for severe COVID-19 illness amongst adults in urban settings.

\section{Keywords}

Malaria, COVID-19, Symptoms

\section{Introduction}

In December 2019, a viral pneumonia disease COVID-19 caused by novel coronavirus SARS-CoV-2, was discovered in Wuhan City, Hubei Province, China and has since created a global disruption in the healthcare system [1]. The disease is transmitted by people in close contact with one another and through respiratory droplets when an infected person coughs or sneezes and the droplet enters the eyes, nose, and mouth [2]. The virulent nature and transmission pattern made the COVID-19 pandemic a serious global health threat [3].

Malaria is a disease burden majorly in the tropical and subtropical region which includes sub-Saharan Africa, Asia and Latin America in which sub-Saharan Africa results in 93 percent of malaria cases and $94 \%$ cases of malaria mortality [4]. In 2018, WHO reported that 50\% of the malaria cases were reported by 6 African countries: Nigeria (25\%), the Democratic Republic of the Congo (12\%), Uganda (5\%), and Côte d'Ivoire, Mozambique and Niger (4\% each). Malaria is an acute febrile illness with flu-like symptoms such as fever, chills, headaches, nausea, vomiting, fatigue and body aches [4]. However, malaria could also cause severe illness majorly by the Plasmodium falciparum, such as severe anemia, kidney failure, cardiac arrest, hypoglycemia in pregnant women (after treatment with quinine), cerebral malaria-seizures, unconsciousness, abnormal behaviour or confusion which can eventually lead to DEATH [5]. People may also develop partial immunity, thus, resulting in asymptomatic infections especially in malaria endemic areas [5]. Risk factors in malaria are majorly children under the age of 5 which is responsible for 67\% (272.000) of malaria deaths [6]. About 125 million pregnant women are also vulnerable to the infection, and in sub-Saharan Africa, about 200,000 infant deaths as a result of gestational malaria have been reported [7] [8]. Medications are now available for the treatment of malaria through the use of drugs such as chloroquine (CQ), doxycycline, quinine, mefloquine, atovaquone/proguanil (Malarone), which were used to treat malaria back then [9]. The first line antimalarial medicine for uncomplicated malaria is now Artemisinin Based Combination Therapies (ACTs) including artemether/lumefantrine and artesunate/amodiaquine [10]. Anti-malaria drugs could also be used by pregnant women and visitors travelling to malaria endemic countries [11]. Malaria preventive methods such as use of insecticides treated nets and indoor spraying of insecticides could also be used [12] (Astatkie, 2010). However, at the moment, there is no specific drug for COVID-19 [13] [14]. Though the 
WHO technical advisory group in 1990-2005 changed its recommendation in malaria-endemic countries like Nigeria from a single dose CQ to the Artemisinin combination therapies (ACTs) because of high rates of drug resistance [15]. $\mathrm{CQ}$ is still commonly prescribed in these regions. Because CQ is now one of the mainstay therapies of COVID-19 all over the world, it has been suggested to play a role through innate immunity, in prevention of COVID-19 in malaria-endemic countries [14]. Hence, our study aims to determine the association that could possibly exist between malaria and COVID-19 in malaria endemic countries like Nigeria.

\section{Methodology}

The study was a cross sectional study, seeking to determine the prevalence of malaria among COVID-19 patients in Nigeria and the role it may play in the diagnosis and management of COVID-19 patients.

\subsection{Enrolment of Participants into the Study}

The participant was randomly selected among individual presenting for testing at the COVID-19 Drive-through testing centre after online pre-registration and informed consent obtained.

\subsection{Data Collection}

Sample size: Data and samples from 617 patients were taken over a between April and May 2020 during the COVID-19 lock downperiod. Patients registered their demographic details as well as details pertaining to symptoms, underlying conditions, travel history, COVID-19 exposure status and BCG vaccination using an online based registration platform.

\subsection{Laboratory Analysis}

Blood and Swab samples (nasopharyngeal and oropharyngeal swab samples) were taken from participants for malaria and SARS-CoV-2 analysis, respectively. Sterile swab was used to collect samples from the nose and throat and placed in a sterile viral transport medium. Corresponding blood samples were collected using a vacutainer needle and $10 \mathrm{ml}$ EDTA vacutainer bottles. Blood samples were examined using commercially available one step malaria antigen P.f (HRP-II) rapid test kit. About 5 Microliters of whole blood samples were transferred into the specimen well, the assay diluent was added in drops (4 drops) and the test kit was left for 15 minutes after which the results were read and collated.

Data from the COVID-19 Testing Management form was extracted for 617 patients. The variables included in this data were age, gender, nationality, marital status, Local Government Area (LGA), points of exposure to COVID-19, pre-existing conditions and COVID-19 symptoms experienced. Collation of both the malaria and COVID-19 datasets resulted in 4 categories of patients, based on their test result. These were: 
1) Patients who tested negative for both malaria and COVID-19.

2) Patients who tested negative for malaria but tested positive for COVID-19.

3) Patients who tested positive for both malaria and COVID-19.

4) Patients who tested positive for malaria but tested negative for COVID-19.

In addition to tests of associations, we sought to determine the factors that could contribute to the patient category. To do this, we fitted a multinomial logistic regression using the patient category as the dependent variable. The model fitted was:

$$
\ln \left(\frac{p(\text { category })}{p(\text { base category })}\right)=b_{0 j}+b_{j i} x_{i}
$$

where: Category of patients $=1$ ) Patients who tested negative for both malaria and COVID-19, 2) Patients who tested negative for malaria but tested positive for COVID-19, 3) Patients who tested positive for both malaria and COVID-19, and 4) Patients who tested positive for malaria but tested negative for COVID-19.

$$
\text { Base category }=\text { both negative patients }
$$

$$
\begin{gathered}
b_{0}=\text { intercept when comparing base category and category } j \\
\qquad \begin{array}{c}
b_{i j}=\text { the coefficient of predictor } X_{i} \\
X_{i}=\text { predictor variable }
\end{array}
\end{gathered}
$$

In this model, we sought to predict what category a patient would fall into, given their symptoms, exposure and other patient characteristics.

All descriptive and inferential analyses were based on these 4 groups. All analyses were conducted using STATA 16 and an alpha level of 0.05 used to determine significance of all test statistics.

\section{Results}

\subsection{COVID-19 and Malaria Prevalence}

Total Prevalence of malaria among COVID-19 Patients was at 0.32\% (Figure 1). Of the 617 participants enrolled for this study, 489 (79.3\%) were negative for

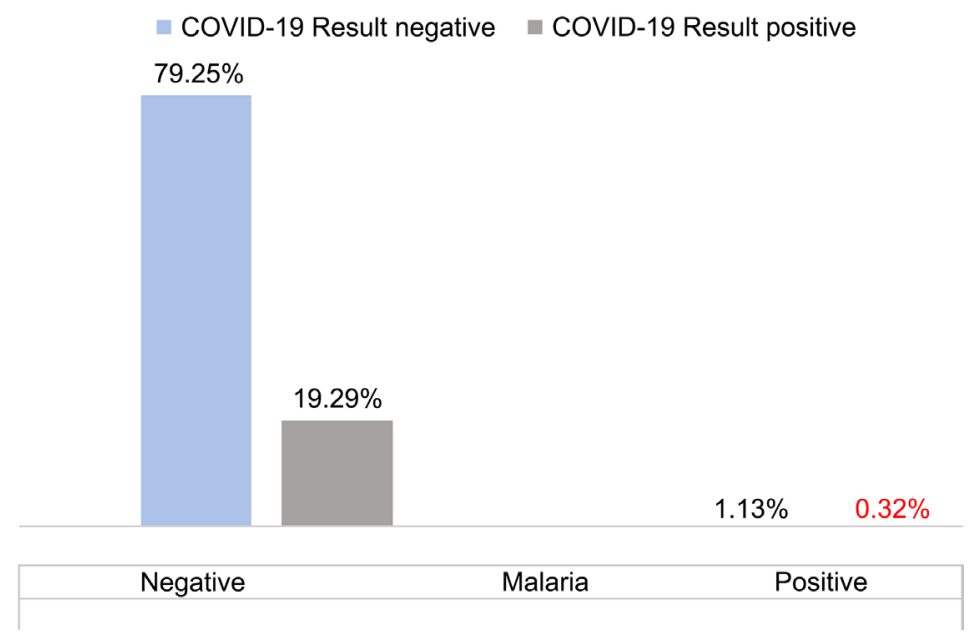

Figure 1. Malaria prevalence in COVID-19 patients. 
both malaria and COVID-19, 119 (19.3\%) were COVID-19 positive and negative for malaria, while 7 (1.1\%) were malaria positive but negative for COVID-19, with only $2(0.3 \%)$ participants had both malaria and COVID-19. A chi-square test of association revealed that there was no association between COVID-19 and malaria test results $\left(\chi^{2}=0.0395, \mathrm{p}=0.842\right)$.

\section{Socio-Demographic Characteristics of Participants}

Within a total of 617 participants, most of them were Nigerian by nationality $(98 \%, \mathrm{n}=604)$. Moreover, the overall mean age of participants was $38( \pm 11)$ years. Among Malaria patients without COVID-19 the mean age was $44( \pm 14)$, $37( \pm 13)$ among COVID-19 patients without malaria, $38( \pm 11)$ among healthy people and among COVID-19 patients who had malaria $34( \pm 11)$. Majority of COVID-19 patients were 30 - 39 years old, while among malaria patients, the majority were 50 - 59 years old.

More than a half (58\%) of the participants were male and they were the majority across all other groups but both malaria and COVID-19 positive had a male and a female. Of all the 617 participants, 374 (61\%) were married, 236 (38\%) were single, $3(0.4 \%)$ divorced and $4(0.6 \%)$ were separated. As shown in Table 1 below.

Table 1. Social demographic characteristics of Participants.

\begin{tabular}{|c|c|c|c|c|c|c|}
\hline \multicolumn{2}{|c|}{ Indicator } & All & Both negative & $\begin{array}{c}\text {-VE malaria, +VE } \\
\text { COVID-19 }\end{array}$ & Both positive & $\begin{array}{c}+\mathrm{VE} \text { malaria, }-\mathrm{VE} \\
\text { COVID-19 }\end{array}$ \\
\hline \multirow{8}{*}{ Age group } & $\leq 9$ & $0.33 \%(\mathrm{n}=2)$ & $0.41 \%(n=2)$ & $0 \%(\mathrm{n}=0)$ & $0 \%(n=0)$ & $0 \%(n=0)$ \\
\hline & 9 to 19 & $1.95 \%(n=12)$ & $1.43 \%(\mathrm{n}=7)$ & $4.2 \%(n=5)$ & $0 \%(n=0)$ & $0 \%(n=0)$ \\
\hline & 20 to 29 & $21.01 \%(n=129)$ & $20.86 \%(n=102)$ & $21.85 \%(n=26)$ & $50 \%(n=1)$ & $29 \%(n=2)$ \\
\hline & 30 to 39 & $39.9 \%(\mathrm{n}=246)$ & $40.29 \%(n=198)$ & $39.5 \%(n=47)$ & $0 \%(\mathrm{n}=0)$ & $14 \%(\mathrm{n}=1)$ \\
\hline & 49 to 49 & $21.66 \%(n=134)$ & $21.47 \%(n=105)$ & $23.53 \%(n=28)$ & $50 \%(n=1)$ & $0 \%(\mathrm{n}=0)$ \\
\hline & 50 to 59 & $11.4 \%(\mathrm{n}=70)$ & $11.66 \%(\mathrm{n}=57)$ & $7.56 \%(\mathrm{n}=9)$ & $0 \%(\mathrm{n}=0)$ & $57 \%(\mathrm{n}=4)$ \\
\hline & 60 to 69 & $3.09 \%(\mathrm{n}=19)$ & $3.68 \%(\mathrm{n}=18)$ & $0.84 \%(n=1)$ & $0 \%(\mathrm{n}=0)$ & $0 \%(\mathrm{n}=0)$ \\
\hline & $\geq 80$ & $0.16 \%(\mathrm{n}=1)$ & $0 \%(\mathrm{n}=0)$ & $0.84 \%(\mathrm{n}=1)$ & $0 \%(\mathrm{n}=0)$ & $0 \%(\mathrm{n}=0)$ \\
\hline \multirow{2}{*}{ Gender } & Male & $58.35 \%(\mathrm{n}=360)$ & $58.16 \%(\mathrm{n}=285)$ & $58.82 \%(\mathrm{n}=70)$ & $50 \%(\mathrm{n}=1)$ & $57 \%(\mathrm{n}=4)$ \\
\hline & Female & $41.65 \%(\mathrm{n}=257)$ & $41.84 \%(n=205)$ & $41.18 \%(n=49)$ & $50 \%(\mathrm{n}=1)$ & $43 \%(n=3)$ \\
\hline \multirow{2}{*}{ Nationality } & Nigerian & $98.05 \%(\mathrm{n}=605)$ & $98.35 \%(n=481)$ & $96.64 \%(n=115)$ & $100 \%(n=2)$ & $100 \%(\mathrm{n}=7)$ \\
\hline & Other & $1.94 \%(\mathrm{n}=12)$ & $1.64 \%(\mathrm{n}=8)$ & $3.36 \%(n=4)$ & $0 \%(\mathrm{n}=0)$ & $0 \%(n=0)$ \\
\hline \multirow{3}{*}{ Marital status } & Married & $60.62 \%(n=374)$ & $60.74 \%(n=297)$ & $57.98 \%(n=69)$ & $100 \%(n=2)$ & $100 \%(\mathrm{n}=7)$ \\
\hline & Single & $38.25 \%(n=236)$ & $38.04 \%(n=186)$ & $41.18 \%(n=49)$ & $0 \%(n=0)$ & $0 \%(n=0)$ \\
\hline & Divorced & $0.49 \%(n=3)$ & $0.61 \%(n=3)$ & $0 \%(\mathrm{n}=0)$ & $0 \%(\mathrm{n}=0)$ & $0 \%(n=0)$ \\
\hline
\end{tabular}




\subsection{COVID-19 Health Seeking Behaviour Pattern}

Data analysed to prove that the response to COVID-19 testing within the Local Government Areas showed that the top 3 LGAs participants came from was Eti-osa $(19.5 \%, \mathrm{n}=123)$, Kosofe $(12 \%, \mathrm{n}=71)$ and Surulere $(11 \%, \mathrm{n}=69)$. The other residents were from Alimosho $(7.9 \%, \mathrm{n}=49)$, Ikeja $(7.1 \%, \mathrm{n}=44)$, Oshodi-Isolo $(7.7 \%, \mathrm{n}=47)$, Lagos Mainland $(5.4 \%, \mathrm{n}=33)$, Apapa $(3.7 \%, \mathrm{n}=23)$ (Table 2).

\subsection{Spread Pattern for COVID-19 and Malaria}

Though the number of malaria cases were exceedingly small, further analysis showed that Malaria prevalence was highest in Alimosho $(33.3 \%, \mathrm{n}=3)$ and Eti-Osa 3, while Ikorodu, Kosefe, Shomolu and Surulere each had 1 patient testing positive for malaria.

Table 2. Distribution of respondent L.G.A in Lagos state and status of both COVID-19 and malaria.

\begin{tabular}{|c|c|c|c|c|}
\hline LGA/State & Frequency (n) & Frequency (\%) & COIVID-19 + cases & Malaria + cases \\
\hline Agege & 11 & 1.8 & $11(4.31 \%)$ & $0(0 \%)$ \\
\hline Alimosho & 51 & 8.3 & $49(7.76 \%)$ & $3(33.3 \%)$ \\
\hline Ajeromi-ifelodun & 3 & 0.5 & $3(1.72 \%)$ & $0(0 \%)$ \\
\hline Amuwo-odofin & 20 & 3.2 & $20(3.45 \%)$ & $0(0 \%)$ \\
\hline Apapa & 23 & 3.7 & $23(4.31 \%)$ & $0(0 \%)$ \\
\hline Badagry & 1 & 0.2 & $1(0 \%)$ & $0(0 \%)$ \\
\hline Eti-osa & 123 & 19.5 & $120(18.1 \%)$ & $2(22.2 \%)$ \\
\hline Ifako-ijaiye & 9 & 1.5 & $9(1.72 \%)$ & $0(0 \%)$ \\
\hline Ikeja & 58 & 9.4 & $44(11.21 \%)$ & $0(0 \%)$ \\
\hline Ikorodu & 17 & 2.8 & $17(2.59 \%)$ & $1(11.1 \%)$ \\
\hline Kosofe & 71 & 12 & $71(11.21 \%)$ & $1(11.1 \%)$ \\
\hline Lagos island & 19 & 3.1 & $19(1.72 \%)$ & $0(0 \%)$ \\
\hline Lagos mainland & 38 & 6.2 & $33(4.31 \%)$ & $0(0 \%)$ \\
\hline Mushin & 17 & 2.8 & $17(2.59 \%)$ & $0(0 \%)$ \\
\hline Ojo & 11 & 1.8 & $11(2.59 \%)$ & $0(0 \%)$ \\
\hline Oshodi-isolo & 47 & 7.7 & $38(10.34 \%)$ & $0(0 \%)$ \\
\hline Shomolu & 29 & 4.7 & $8(0.86 \%)$ & $1(11.1 \%)$ \\
\hline Surulere & 69 & 11 & $69(11.21 \%)$ & $1(11.5 \%)$ \\
\hline
\end{tabular}




\subsection{Exposure to COVID-19}

Respondents reported several points of exposure. Out of the 617 participants, 315 (51\%) had contact with a COVID-19 suspect, 281 (46\%) were employed by a case facility, 77 (12\%) had attended mass gathering, 48 (8\%) had contact with overseas travelers. The distribution across the 4 patient categories is as shown in Table 3 below. Based on the NCDC exposure criteria, 613 (99\%) were deemed to be at risk of contracting COVID-19 out of the 617 respondents. However, only 121 respondents tested positive for COVID-19 leaving the COVID-19 prevalence rate among respondents to be $19.7 \%$.

\subsubsection{Influence of BCG Vaccination on COVID-19 Infection Rate}

When asked if they had received the BCG vaccine, 291(47\%) of the respondents reported that they had received BCG vaccination in their lifetime, 94 (15\%) did not receive and 232 (38\%) were not sure (Table 4). Further analysis done on those who were tested for COVID-19 showed that $56.2 \%$ of those who reported to have received BCG Vaccine tested positive for COVID-19. However, a chi-square test of association between BCG Vaccine and COVID Results showed that there was no statistically significant association at alpha $=0.05\left(\chi^{2}=5.210, p=0.074\right)$.

\subsubsection{COVID-19 and Preexisting Conditions}

Majority of respondents had no pre-existing conditions (85\%). Among COVID-19 patients, $(85 \%, \mathrm{n}=101)$ had no pre-existing conditions, $7 \%$ had heart diseases, other pre-existing conditions listed by COVID-19 patients were asthma (3\%), hypertension (3\%), pregnancy (3\%), obesity (2\%), chronic liver disease $(2 \%)$, chronic kidney disease (1\%), chronic lung disease (1\%), and anaemia or chronic haematology (1\%). Among the 257 female participants, 8 (3\%) were pregnant of which $2(25 \%)$ of these pregnant women were COVID-19 positive.

Table 3. Exposure to COVID-19 for all participants groups.

\begin{tabular}{|c|c|c|c|c|c|c|}
\hline Indicator & & All & Both negative & $\begin{array}{c}\text {-VE malaria, +VE } \\
\quad \text { COVID-19 }\end{array}$ & Both positive & $\begin{array}{c}+\mathrm{VE} \text { malaria, }-\mathrm{VE} \\
\text { COVID }\end{array}$ \\
\hline \multirow{2}{*}{$\begin{array}{l}\text { Had contact with } \\
\text { suspect }\end{array}$} & No & $48.95 \%(\mathrm{n}=302)$ & $50.51 \%(\mathrm{n}=247)$ & $43.7 \%(n=52)$ & $0 \%(\mathrm{n}=0)$ & $33 \%(\mathrm{n}=3)$ \\
\hline & Yes & $51.05 \%(\mathrm{n}=315)$ & $49.49 \%(\mathrm{n}=242)$ & $56.3 \%(\mathrm{n}=67)$ & $100 \%(\mathrm{n}=2)$ & $67 \%(\mathrm{n}=6)$ \\
\hline \multirow{2}{*}{$\begin{array}{l}\text { Is employed by } \\
\text { case management } \\
\text { facility }\end{array}$} & No & $54.45 \%(\mathrm{n}=336)$ & $54.69 \%(\mathrm{n}=268)$ & $51.26 \%(\mathrm{n}=61)$ & $100 \%(\mathrm{n}=2)$ & $78 \%(\mathrm{n}=7)$ \\
\hline & Yes & $45.54 \%(\mathrm{n}=281)$ & $45.31 \%(n=222)$ & $48.74 \%(\mathrm{n}=58)$ & $0 \%(\mathrm{n}=0)$ & $22 \%(\mathrm{n}=2)$ \\
\hline \multirow{2}{*}{$\begin{array}{l}\text { Had attended mass } \\
\text { gathering }\end{array}$} & No & $87.5 \%(\mathrm{n}=540)$ & $86.73 \%(n=424)$ & $90.76 \%(n=108)$ & $100 \%(\mathrm{n}=2)$ & $89 \%(\mathrm{n}=8)$ \\
\hline & Yes & $12.5 \%(\mathrm{n}=77)$ & $13.27 \%(\mathrm{n}=65)$ & $9.24 \%(\mathrm{n}=11)$ & $0 \%(\mathrm{n}=0)$ & $11 \%(\mathrm{n}=1)$ \\
\hline \multirow{2}{*}{$\begin{array}{l}\text { Had contact with } \\
\text { overseas traveler }\end{array}$} & No & $92.22 \%(\mathrm{n}=569)$ & $92 \%(\mathrm{n}=445)$ & $97.48 \%(\mathrm{n}=116)$ & $100 \%(\mathrm{n}=2)$ & $89 \%(\mathrm{n}=8)$ \\
\hline & Yes & $7.78 \%(\mathrm{n}=48)$ & $8 \%(\mathrm{n}=43)$ & $2.52 \%(\mathrm{n}=3)$ & $0 \%(\mathrm{n}=0)$ & $11 \%(\mathrm{n}=1)$ \\
\hline
\end{tabular}




\subsubsection{COVID-19 Symptoms Presented by Study Participants}

More than half of the respondents $(52 \%, \mathrm{n}=320)$ reported that they had no symptoms. However, those who had symptoms mentioned fever $(29 \%, \mathrm{n}=177)$, sore throat $(24 \%, \mathrm{n}=145)$ and dry cough $(20 \%, \mathrm{n}=121)$ as the top three symptoms. Other symptoms are as shown in Table 5 below.

Table 4. Frequency distribution of BCG vaccine among participants.

\begin{tabular}{cccc}
\hline \multirow{2}{*}{ BCG vaccine } & \multicolumn{3}{c}{ COVID Result } \\
\cline { 2 - 4 } & Negative & Positive & Total \\
\hline No & 77 & 17 & 94 \\
\% of total & 15.52 & 14.05 & 15.24 \\
Not sure & 196 & 36 & 232 \\
\% of total & 39.52 & 29.75 & 37.6 \\
Yes & 223 & 69 & 291 \\
\% of total & 44.96 & 56.2 & 47.16 \\
Total & 427 & 116 & 543 \\
\% of total & 78.64 & 21.36 & 100 \\
\hline
\end{tabular}

Table 5. Frequency distribution of symptoms reported by respondents.

\begin{tabular}{|c|c|c|c|}
\hline Symptom & $\%(\mathrm{n})$ & Symptom & $\%(\mathrm{n})$ \\
\hline no symptoms & $51.95 \%(n=320)$ & $\begin{array}{l}\text { known contact with } \\
\text { positive COVID-19 } \\
\text { patients that resulted } \\
\text { in death }\end{array}$ & $0.97 \%(n=6)$ \\
\hline Fever & $28.73 \%(\mathrm{n}=177)$ & nausea & $0.49 \%(\mathrm{n}=3)$ \\
\hline sore throat & $23.58 \%(n=145)$ & no appetite & $0.49 \%(\mathrm{n}=3)$ \\
\hline dry cough & $19.64 \%(n=121)$ & back pain & $0.16 \%(\mathrm{n}=1)$ \\
\hline shortness of breath & $15.91 \%(\mathrm{n}=98)$ & choking & $0.16 \%(\mathrm{n}=1)$ \\
\hline nasal congestion & $14.29 \%(\mathrm{n}=88)$ & high blood pressure & $0.16 \%(\mathrm{n}=1)$ \\
\hline running nose & $9.74 \%(\mathrm{n}=60)$ & indigestion & $0.16 \%(\mathrm{n}=1)$ \\
\hline abdominal pain & $9.74 \%(n=60)$ & insomnia and sweating & $0.16 \%(\mathrm{n}=1)$ \\
\hline Diarrhea & $7.63 \%(n=47)$ & loss of taste & $0.16 \%(\mathrm{n}=1)$ \\
\hline Headache & $3.73 \%(n=23)$ & loss of smell & $0.16 \%(\mathrm{n}=1)$ \\
\hline chest pain & $2.76 \%(\mathrm{n}=17)$ & dizziness & $0.16 \%(\mathrm{n}=1)$ \\
\hline muscle pain & $2.11 \%(\mathrm{n}=13)$ & dry mouth & $0.16 \%(\mathrm{n}=1)$ \\
\hline Fatigue & $1.46 \%(\mathrm{n}=9)$ & previously tested positive & $0.16 \%(\mathrm{n}=1)$ \\
\hline
\end{tabular}




\subsection{Tests of Associations and Correlations}

In addition to correlations, we tested the association of each category with the independent variables (Table 6). There was no variable found to be significantly associated to patient categories at alpha $=0.05$ as shown on the table below.

\subsection{Bivariate and Multivariate Analysis}

Using the multinomial logit model, we sought to check what are the factors that could be used to predict the category the participants falls into. We first fitted a bivariate model. From this, dry cough (coeff $=0.87, \mathrm{p}=0.018$ ), fatigue (coeff $=$ 3.06, $\mathrm{p}=0.01$ ), had known contact with positive COVID-19 patients (coeff = 2.37, $\mathrm{p}=0.01)$ and contact with an overseas traveler (coeff $=-1.31, \mathrm{p}=0.030$ ) can significantly explain patients that negative for malaria but positive for COVID-19 category. The same holds in the multivariate model as shown in Appendix 1. This means that a unit increase in each of these variables is associated with a corresponding increase/decrease in the relative log odds of being negative for malaria but positive for COVID-19.

\section{Discussion}

The emergence of SARS-CoV-2 has brought about different postulations concerning its mode of transmission, symptoms associated with its infection, mortality rate etc. One of these said postulations lay emphasis on its relationship with malaria, it's been reported that malaria and COVID-19 share similar symptoms and could lead to misleading diagnosis, some regions (especially regions having high malaria prevalence) believe COVID-19 is the same as malaria [16]. These

Table 6. Tests of associations with Respondent categories.

\begin{tabular}{ccc}
\hline Associations with category of patients & Pearson chi2 (df) & P value \\
\hline age group & $36(24)$ & 0.055 \\
contact with suspect & $3.81(3)$ & 0.282 \\
employed by case facility & $3(3)$ & 0.392 \\
attended mass gathering & $1.74(3)$ & 0.627 \\
contact with traveler & $6.18(3)$ & 0.103 \\
qualified case & $0.14(3)$ & 0.987 \\
bcg vaccine & $7.78(6)$ & 0.255 \\
gender & $0.07(3)$ & 0.995 \\
marital status & $4.39(9)$ & 0.884 \\
LGA & $80.83(90)$ & 0.745 \\
symptom & $65.98(75)$ & 0.762 \\
pre existing condition & $11.32(45)$ & 0.999
\end{tabular}


notions had hindered people who might have been infected with this virus from seeking appropriate medical attention under the guise that they may be having malaria. The confirmation or dismissal of this notion formed the basis of this study.

The findings from this study support the evidence that malaria endemicity has no association with COVID-19 infection. Since our study was conducted in a malaria endemic setting where it has been reported that half of the adult population could have at least one episode of malaria annually, our findings point towards a review of malaria incidences in these settings because of the low prevalence outcome. It could be argued that malaria parasite microscopy is the gold standard for malaria diagnosis, however, the RDT test kit used has been validated using microscopy, it is the most employed in malaria diagnosis in the country due to its low cost and rapid turnaround time. It has been opined that, prevalence of malaria is low in urban settings [17]. Our study is a mixed population of both urban and rural settings with participants spread across 18 local governments in Lagos State, with results showing that there is an occurrence of low malaria prevalence. Furthermore, the rainy season is here and malaria infection is expected to rise significantly during the rainy season which coincide with the period of this study, however, the low prevalence of malaria reported in this could mean a shift in paradigm as far as malaria endemicity is concerned. In addition, malaria is prevalent among children 5 years and below, however, this population was very few in our study [18]. This could be a limitation and the reason why malaria prevalence outcome from this study is exceptionally low.

More than half of the participants in this study were asymptomatic. However, fever, sore throat and dry cough are the most experienced symptoms among participants. This correlated with data from previous reviews on similar study in which the most common presenting symptoms are the same [19]. Our findings also provide a compelling evidence that disprove the theory that COVID-19 pandemic could complicate malaria diagnosis due to similarities in symptoms such as raised body temperature, headache and body ache that characterise both diseases as the two cases with COVID-19-Malaria Co-infection reported in our study were asymptomatic. Hence there is a need to further investigate factors responsible for low malaria prevalence at the height of COVID-19 spread in the country.

Though disease outbreaks affect men and women differently, this study showed that both genders responded to testing similarly and the male population had a similar COVID-19 infection rate with the female counterpart. Though contrary to a previous report from Bowale et al. [20], this outcome conforms to the study released by the Global Health 50/50 project which states that there are similarities in the COVID-19 incidence rate in both male and female [21]. Age group was significantly associated with the disease categories in this study. Epidemiologically, it has been reported that people who are at most risk of death from COVID-19 are the vulnerable groups comprising the elderly, chronically ill 
and immuno-compromised such as people already suffering from diabetes, heart diseases, HIV and tuberculosis. Nevertheless, our findings showed that the majority who reported for testing were young adults (between 30 and 49). This might be connected to the fact that this age category forms the larger portion of Nigeria's population and could be one of the factors behind the low death recorded for COVID-19 in the country.

Furthermore, though the majority of participants had no pre-existing conditions, heart disease is the most reported underlying factor among COVID-19 patients in this study. Most importantly, we found that dry cough, fatigue, known contact with positive COVID-19 patients, and contact with an overseas traveler significantly explain COVID-19 infection rate. These agree with other findings on characteristics and nature of symptoms and transmission route of COVID-19 [22] [23] [24].

\section{Conclusion}

In conclusion, there is no significant prevalence of malaria amongst patients presenting themselves for COVID testing. However, there is sufficient statistical evidence to show that if a patient exhibits symptoms such as dry cough, abdominal pain and fatigue, and had known contact with positive COVID-19 patients and contact with an overseas traveler, they are more likely to test positive for COVID-19. In addition, this confirms that malaria is not the same, neither is it among the underlying medical conditions strongly associated with increased risk for severe COVID-19 illness among adults.

\section{Conflicts of Interest}

The authors declare no conflicts of interest regarding the publication of this paper.

\section{References}

[1] Zhu, N., Zhang, D.Y., Wang W.L., et al. (2020) A Novel Coronavirus from Patients with Pneumonia in China, 2019. The New England Journal of Medicine, 382, 727-733.

[2] World Health Organization (WHO) (2020) Coronavirus Disease 2019 (COVID19)-Situation Report-39.

https://www.who.int/docs/default-source/coronaviruse/situation-reports/20200228sitrep-39-COVID-19.pdf?sfvrsn=aa1b80a74

[3] World Health Organization (WHO). Coronavirus Disease 2019 (COVID-19). https://www.who.int/news-room/commentaries/detail/modes-of-transmission-of-vi rus-causing-COVID-19-implications-for-ipc-precaution-recommendations

[4] World Health Organization (WHO). Malaria Key Facts 2018. http://www.who.int/news-room/fact-sheets/detail/malaria

[5] Taylor-Robinson, D., Jones, K., Garner, P. and Sinclair, D. (2008) Malaria: Uncomplicated, Caused by Plasmodium Falciparum. Clinical Evidence, 1, 919.

[6] Roberts, D. and Matthews, G. (2016) Risk Factors of Malaria in Children under the Age of Five Years Old in Uganda. Malaria Journal, 15, Article No. 246. 
https://doi.org/10.1186/s12936-016-1290-X

[7] Hartman, T.K., Rogerson, S.J. and Fischer, P.R. (2010) The Impact of Maternal Malaria on Newborns. Annals of Tropical Pediatric, 30, 271-282. https://doi.org/10.1179/146532810X12858955921032

[8] Bardají, A., Sigauque, B., Sanz, S., Maixenchs, M., Ordi, J., Aponte, J.J., Mabunda, S., Alonso, P.L. and Menéndez, C. (2011) Impact of Malaria at the End of Pregnancy on Infant Mortality and Morbidity Journal of Infectious Disease, 203, 691-699. https://doi.org/10.1093/infdis/jiq049

[9] Tan, R.K., Magill, A.J., Parise, M.E. and Arguin P.M. (2011) Doxycycline for Malaria Chemoprophylaxis and Treatment: Report from the CDC Expert Meeting on Malaria Chemoprophylaxis. American Journal of Tropical Medicine and Hygiene, 84, 517-531. https://doi.org/10.4269/ajtmh.2011.10-0285

[10] Msellem, M., Morris, U., Soe, A., Abbas, F.B., Ali, A., Barnes, R., Frumento, P., Ali, A.S., Martensson, A. and Björkman, A. (2020). Increased Sensitivity of Plasmodium Falciparum to Artesunate/Amodiaquine despite 14 Years as First-Line Malaria Treatment, Zanzibar. Emerging Infectious Diseases, 26, 1767-1777. https://doi.org/10.3201/eid2608.191547

[11] Center for Disease Control (CDC) (2020) Malaria and Travelers. https://www.cdc.gov/malaria/travelers/drugs.html

[12] Astatkie, A. (2010) Knowledge and Practice of Malaria Prevention Methods among Residents of Arba Minch Town and Arba Minch Zuria District, Southern Ethiopia. Ethiopian Journal of Health Sciences, 20, 185-193. https://doi.org/10.4314/ejhs.v20i3.69448

[13] Centre for Disease Control (CDC) (2020) COVID-19 Treatment Guidelines Panel. Coronavirus Disease 2019 (COVID-19) Treatment Guidelines. National Institutes of Health. https://www.COVID19treatmentguidelines.nih.gov/

[14] Shi, H.I., W, C.J., Tu, Y.F. and Chi, C.Y. (2020) Fighting COVID-19: A Quick Review of Diagnoses, Therapies, and Vaccines. Biomedical Journal. https://doi.org/10.1016/j.bj.2020.05.021

[15] Flegg, J., Metcalf, J., Gharbi, M., Venkatesan, M., Shewchuk, T., Sibley, C. and Guerin, P. (2013) Trends in Antimalarial Drug Use in Africa. The American Journal of Tropical Medicine and Hygiene, 89, 857-865.

https://doi.org/10.4269/ajtmh.13-0129

[16] Chanda-Kapata, P., Kapata, N. and Zumla, A. (2020). COVID-19 and Malaria: A Symptom Screening Challenge for Malaria Endemic Countries. International Journal of Infectious Diseases, 94, 151-153. https://doi.org/10.1016/j.ijid.2020.04.007

[17] Tatem, A.J., Gething, P.W., Smith, D.L. and Hay, S.I. (2013) Urbanization and the Global Malaria Recession. Malaria Journal, 12, Article No, 13. https://doi.org/10.1186/1475-2875-12-133

[18] Nyarko, S.H. and Cobblah, A. (2014) Sociodemographic Determinants of Malaria among Under-Five Children in Ghana. Malaria Research and Treatment, 2014, Article ID: 304361. https://doi.org/10.1155/2014/304361

[19] World Health Organization (2020) Tailoring Malaria Interventions in the COVID-19 Response. World Health Organization, Geneva.

[20] Global Health 5050 Report. (2020) COVID-19 Sex-Disaggregated Data Tracker. https://globalhealth5050.org/the-sex-gender-and-covid-19-project/

[21] Bowale, A., et al. (2020) Clinical Presentation, Case Management and Outcomes for the First 32 COVID-19 Patients in Nigeria. Pan African Medical Journal, 35, 24. 
https://doi.org/10.11604/pamj.supp.2020.35.2.23262

[22] Chena, H.X., Ai, L., Lu, H. and Li, H. (2020) Clinical and Imaging Features of COVID-19. Radiology of Infectious Diseases, 7, 43-50.

https://doi.org/10.1016/j.jrid.2020.04.003

[23] Pani, S.K., Lin, N. and Ravindrababu, S. (2020). Association of COVID-19 Pandemic with Meteorological Parameters over Singapore. Science of the Total Environment, 740, Article ID: 140112. https://doi.org/10.1016/j.scitotenv.2020.140112

[24] Ribeiro, A.L.R. and Sousa, N.W.A. (2020) Besides the Climate Model, Other Variables Driving the COVID-19 Spread in Brazil. Science of the Total Environment, 737, Article ID: 140211. https://doi.org/10.1016/j.scitotenv.2020.140211 


\section{Appendix 1}

\begin{tabular}{|c|c|c|c|c|c|c|c|}
\hline \multirow{2}{*}{ Variable } & $\begin{array}{l}\text {-VE Malaria } \\
\text { +COVID }\end{array}$ & Both negative & $\begin{array}{l}\text { +VE Malaria } \\
\text {-VE COVID }\end{array}$ & \multirow{2}{*}{ variable } & $\begin{array}{l}\text {-VE Malaria } \\
\text { +COVID }\end{array}$ & \multicolumn{2}{|l|}{ Both negative } \\
\hline & coeff (se) & coeff (se) & coeff (se) & & coeff (se) & coeff (se) & coeff (se) \\
\hline \multicolumn{4}{|c|}{ age group } & \multicolumn{4}{|c|}{ conditions categories } \\
\hline 0 to 9 & ref & & & $\begin{array}{l}\text { no pre-existing } \\
\text { condition }\end{array}$ & ref & & \\
\hline 9 to 19 & $\begin{array}{c}15.33 \\
(1782.31)\end{array}$ & $\begin{array}{c}0.59 \\
(14,798.06)\end{array}$ & $\begin{array}{c}0.59 \\
(7909.9)\end{array}$ & asthma & $\begin{array}{c}-13.42 \\
(3150.63)\end{array}$ & $\begin{array}{c}-13.42 \\
(1684.08)\end{array}$ & $\begin{array}{c}-13.42 \\
(1684.08)\end{array}$ \\
\hline 20 to 29 & $\begin{array}{c}14.32 \\
(1782.31)\end{array}$ & $\begin{array}{c}15.15 \\
(13,748.07)\end{array}$ & $\begin{array}{c}14.59 \\
(7348.66)\end{array}$ & $\begin{array}{l}\text { chronic kidney } \\
\text { disease }\end{array}$ & $\begin{array}{c}-13.71 \\
(13,593.72)\end{array}$ & $\begin{array}{c}-13.71 \\
(7266.15)\end{array}$ & $\begin{array}{c}-13.71 \\
(7266.15)\end{array}$ \\
\hline 30 to 39 & $\begin{array}{c}14.23 \\
(1782.31)\end{array}$ & $\begin{array}{c}0.36 \\
(13,796.51)\end{array}$ & $\begin{array}{c}13.21 \\
(7348.66)\end{array}$ & $\begin{array}{c}\text { chronic liver } \\
\text { disease }\end{array}$ & $\begin{array}{c}-13.27 \\
(6286.64)\end{array}$ & $\begin{array}{c}-13.27 \\
(3360.35)\end{array}$ & $\begin{array}{c}-13.27 \\
(3360.35)\end{array}$ \\
\hline 49 to 49 & $\begin{array}{c}14.34 \\
(1782.31)\end{array}$ & $\begin{array}{c}15.1 \\
(13,748.07)\end{array}$ & $\begin{array}{c}0.38 \\
(7396.35)\end{array}$ & chronic cough & $\begin{array}{c}-13.71 \\
(13,593.72)\end{array}$ & $\begin{array}{c}-13.71 \\
(7266.15)\end{array}$ & $\begin{array}{c}-13.71 \\
(7266.15)\end{array}$ \\
\hline 50 to 59 & $\begin{array}{c}13.82 \\
(1782.31)\end{array}$ & $\begin{array}{c}0.28 \\
(13,928.75)\end{array}$ & $\begin{array}{c}15.84 \\
(7348.66)\end{array}$ & hypertension & $\begin{array}{c}-13.24 \\
(3586.18)\end{array}$ & $\begin{array}{c}-13.24 \\
(1916.9)\end{array}$ & $\begin{array}{c}-13.24 \\
(1916.9)\end{array}$ \\
\hline 60 to 69 & $\begin{array}{c}12.77 \\
(1782.31)\end{array}$ & $\begin{array}{c}0.13 \\
(14,401.56)\end{array}$ & $\begin{array}{c}0.13 \\
(7697.96)\end{array}$ & diabetes & $\begin{array}{c}-13.71 \\
(9612.22)\end{array}$ & $\begin{array}{c}-13.71 \\
(5137.95)\end{array}$ & $\begin{array}{c}-13.71 \\
(5137.95)\end{array}$ \\
\hline 70 to 79 & $\begin{array}{c}16.36 \\
(1782.31)\end{array}$ & $\begin{array}{c}0.92 \\
(18,422.15)\end{array}$ & $\begin{array}{c}0.92 \\
(9847.06)\end{array}$ & heart disease & $\begin{array}{c}-13.25 \\
(2881.89)\end{array}$ & $\begin{array}{c}-13.25 \\
(1540.44)\end{array}$ & $\begin{array}{c}-13.25 \\
(1540.44)\end{array}$ \\
\hline 80 and above & $\begin{array}{c}30.75 \\
(2592.31)\end{array}$ & $\begin{array}{c}14.25 \\
(32,513.88)\end{array}$ & $\begin{array}{c}14.25 \\
(17452.07)\end{array}$ & $\begin{array}{l}\text { haemorrhoid } \\
\text { issue }\end{array}$ & $\begin{array}{c}-13.71 \\
(13,593.72)\end{array}$ & $\begin{array}{c}-13.71 \\
(7266.15)\end{array}$ & $\begin{array}{c}-13.71 \\
(7266.15)\end{array}$ \\
\hline constant & $\begin{array}{c}-15.66 \\
(1782.31)\end{array}$ & $\begin{array}{c}-19.75 \\
(13,748.07)\end{array}$ & $\begin{array}{c}-18.5 \\
(7348.66)\end{array}$ & ulcers & $\begin{array}{c}-13.71 \\
(7848.34)\end{array}$ & $\begin{array}{c}-13.71 \\
(4195.11)\end{array}$ & $\begin{array}{c}-13.71 \\
(4195.11)\end{array}$ \\
\hline & contact $\mathrm{v}$ & suspect & & obesity & $\begin{array}{l}-1.3 \\
(1.04)\end{array}$ & $\begin{array}{c}-14.53 \\
(7493.7)\end{array}$ & $\begin{array}{c}-14.53 \\
(7493.7)\end{array}$ \\
\hline no & ref & & & pregnancy & $\begin{array}{c}-13.25 \\
(4821.06)\end{array}$ & $\begin{array}{c}-13.25 \\
(2576.97)\end{array}$ & $\begin{array}{c}-13.25 \\
(2576.97)\end{array}$ \\
\hline yes & $\begin{array}{c}0.27 \\
(0.21)\end{array}$ & $\begin{array}{c}15.24 \\
(1426.13)\end{array}$ & $\begin{array}{c}0.31 \\
(0.77)\end{array}$ & $\begin{array}{l}\text { chronic lung } \\
\text { disease }\end{array}$ & $\begin{array}{c}-13.71 \\
(7848.34)\end{array}$ & $\begin{array}{c}-13.71 \\
(4195.11)\end{array}$ & $\begin{array}{c}-13.71 \\
(4195.11)\end{array}$ \\
\hline constant & $\begin{array}{c}-1.56 \\
(0.15)^{\star * *}\end{array}$ & $\begin{array}{c}-20.03 \\
(1426.13)\end{array}$ & $\begin{array}{c}-4.41 \\
(0.58)^{* * *}\end{array}$ & hyperthyroidism & $\begin{array}{c}-13.71 \\
(13,593.72)\end{array}$ & $\begin{array}{c}-13.71 \\
(7266.15)\end{array}$ & $\begin{array}{c}-13.71 \\
(7266.15)\end{array}$ \\
\hline & attended $\mathrm{m}$ & gathering & & $\begin{array}{c}\text { anaemia or chronic } \\
\text { haematology }\end{array}$ & $\begin{array}{c}-14.54 \\
(2895.33)\end{array}$ & $\begin{array}{c}-14.7 \\
(31584.36)\end{array}$ & $\begin{array}{c}-14.7 \\
(31584.36)\end{array}$ \\
\hline no & ref & & & $\begin{array}{l}\text { other chronic rare } \\
\text { conditions }\end{array}$ & $\begin{array}{c}-13.27 \\
(6286.64)\end{array}$ & $\begin{array}{c}-13.27 \\
(3360.35)\end{array}$ & $\begin{array}{c}-13.27 \\
(3360.35)\end{array}$ \\
\hline yes & $\begin{array}{l}-0.41 \\
(0.34)\end{array}$ & $\begin{array}{c}-12.34 \\
(865.32)\end{array}$ & $\begin{array}{c}0.08 \\
(1.09)\end{array}$ & constant & $\begin{array}{c}-5.33 \\
(0.71)^{* * *}\end{array}$ & $\begin{array}{c}-4.07 \\
(0.38)^{* * *}\end{array}$ & $\begin{array}{c}-4.07 \\
(0.38)^{* * *}\end{array}$ \\
\hline
\end{tabular}




\section{Continued}

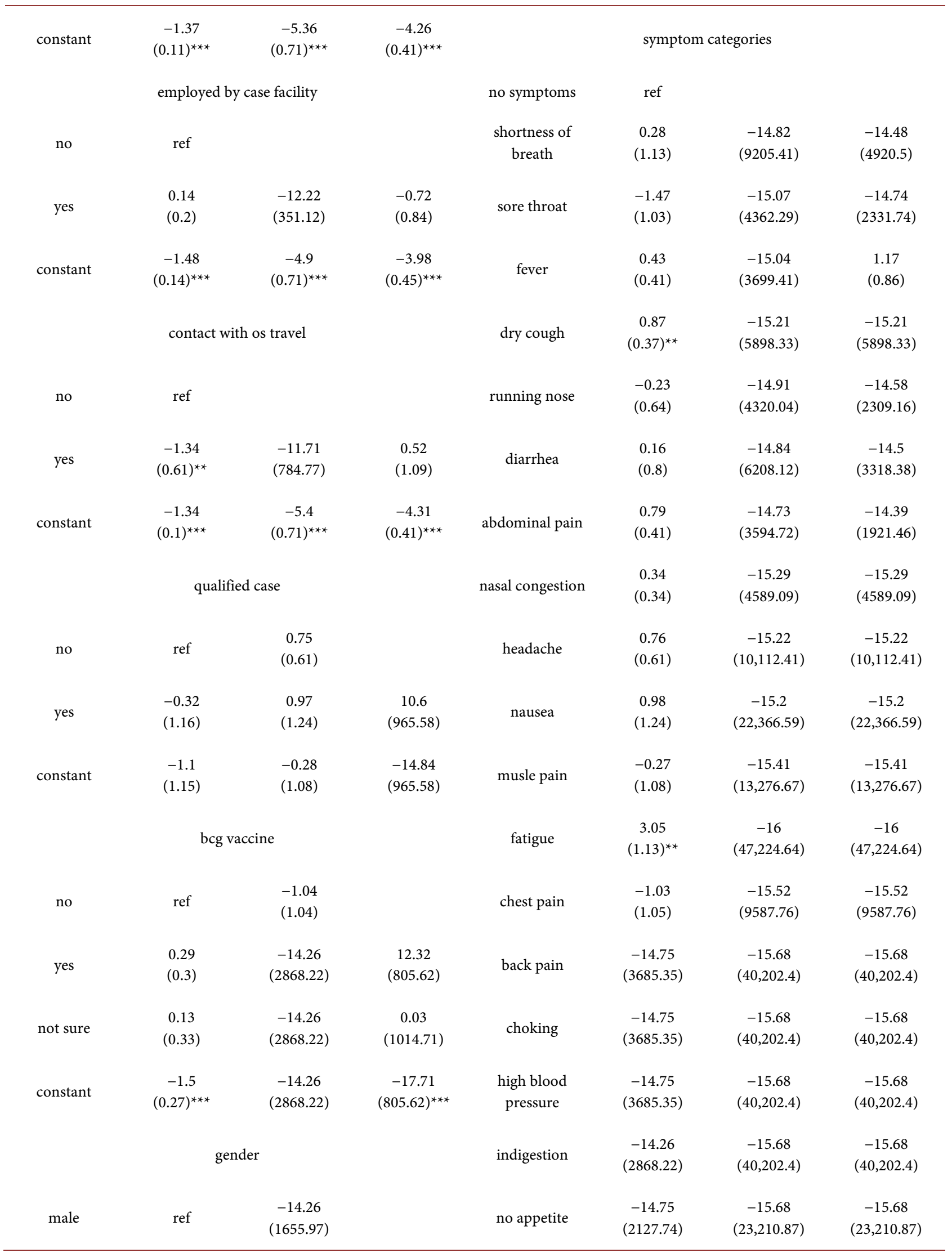




\section{Continued}

\begin{tabular}{|c|c|c|c|c|c|c|c|}
\hline female & $\begin{array}{l}-0.02 \\
(0.21)\end{array}$ & $\begin{array}{c}0.33 \\
(1.42)\end{array}$ & $\begin{array}{c}0.05 \\
(0.77)\end{array}$ & $\begin{array}{l}\text { known contact } \\
\text { with positive } \\
\text { COVID-19 } \\
\text { patients that } \\
\text { resulted in death }\end{array}$ & $\begin{array}{c}2.36 \\
(0.88)^{\star *}\end{array}$ & $\begin{array}{c}-15.14 \\
(15,300.21)\end{array}$ & $\begin{array}{c}-14.8 \\
(8178.31)\end{array}$ \\
\hline \multirow[t]{2}{*}{ constant } & $\begin{array}{c}-1.4 \\
(0.13)^{\star * *}\end{array}$ & $\begin{array}{l}-5.65 \\
(1)^{* * *}\end{array}$ & $\begin{array}{c}-4.27 \\
(0.5)^{* * *}\end{array}$ & $\begin{array}{l}\text { insomnia and } \\
\text { sweating }\end{array}$ & $\begin{array}{c}-14.26 \\
(2868.22)\end{array}$ & $\begin{array}{c}-15.18 \\
(22,124.4)\end{array}$ & $\begin{array}{c}-14.85 \\
(11,825.99)\end{array}$ \\
\hline & \multicolumn{2}{|c|}{ marital status } & & loss of taste & $\begin{array}{c}19.09 \\
(6047.92)\end{array}$ & $\begin{array}{c}-0.67 \\
(133,876.5)\end{array}$ & $\begin{array}{c}-0.67 \\
(133,876.5)\end{array}$ \\
\hline married & ref & & & loss of smell & $\begin{array}{c}18.6 \\
(4747.27)\end{array}$ & $\begin{array}{c}-0.67 \\
(74,306.58)\end{array}$ & $\begin{array}{c}-0.34 \\
(39,920.67)\end{array}$ \\
\hline single & $\begin{array}{c}0.13 \\
(0.21)\end{array}$ & $\begin{array}{c}-14.62 \\
(1338.54)\end{array}$ & $\begin{array}{l}-1.32 \\
(1.08)\end{array}$ & dizziness & $\begin{array}{c}-14.26 \\
(2868.22)\end{array}$ & $\begin{array}{c}-15.18 \\
(22,124.4)\end{array}$ & $\begin{array}{c}-14.85 \\
(11,825.99)\end{array}$ \\
\hline divorced & $\begin{array}{c}-14.49 \\
(1679.69)\end{array}$ & $\begin{array}{c}-15.04 \\
(12,956.51)\end{array}$ & $\begin{array}{c}-14.88 \\
(6925.55)\end{array}$ & dry mouth & $\begin{array}{c}18.6 \\
(4747.27)\end{array}$ & $\begin{array}{c}-0.67 \\
(74,306.58)\end{array}$ & $\begin{array}{c}-0.34 \\
(39,920.67)\end{array}$ \\
\hline separated & $\begin{array}{c}0.36 \\
(1.16)\end{array}$ & $\begin{array}{c}-14.59 \\
(10,383.73)\end{array}$ & $\begin{array}{c}-14.44 \\
(5550.34)\end{array}$ & $\begin{array}{l}\text { previously tested } \\
\text { positive }\end{array}$ & $\begin{array}{c}18.6 \\
(4747.27)\end{array}$ & $\begin{array}{c}-0.67 \\
(74,306.58)\end{array}$ & $\begin{array}{c}-0.34 \\
(39,920.67)\end{array}$ \\
\hline constant & $\begin{array}{c}-1.46 \\
(0.13)^{* * *}\end{array}$ & $\begin{array}{c}-5 \\
(0.71)^{\star * *}\end{array}$ & $\begin{array}{c}-3.9 \\
(0.41)^{* * *}\end{array}$ & constant & $\begin{array}{c}-1.67 \\
(0.16)^{\star * *}\end{array}$ & $\begin{array}{c}-4.82 \\
(0.71)^{* * *}\end{array}$ & $\begin{array}{c}-3.91 \\
(0.45)^{* * *}\end{array}$ \\
\hline
\end{tabular}

